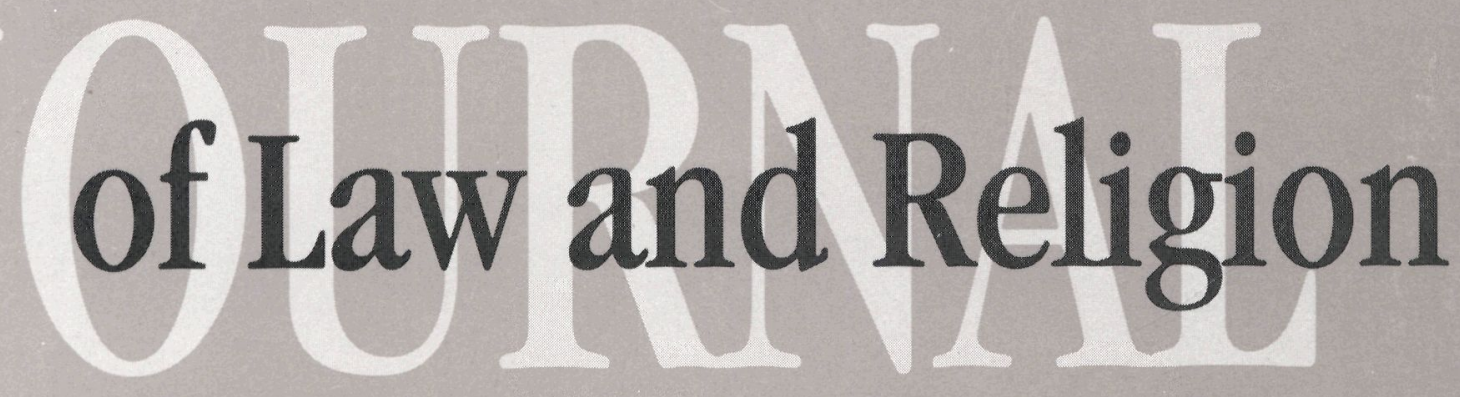

\section{Volume XXI}

\section{Number 1}

\section{5-2006}

\begin{abstract}
Articles
Asking the Right Questions: Harnessing the Insights of Bernard Lonergan for the Rule of Law

Patrick McKinley Brennan

Legal Theology: The Turn to Conceptualism in Nineteenth-Century Jewish Law

Chaim Saiman

Christian Scripture and American Scripture:

An Instructive Analogy?

Gregory A. Kalscheur, S.J.

The Use of Natural Law in Early Calvinist Resistance Theory

David VanDrunen
\end{abstract}

\section{Review Essays}

Religion in the World

Carolyn Evans

Religion and Politics in the United States

Marci A. Hamilton

\section{Book Reviews}

Taking Faith Seriously,

edited by Mary Jo Bane, Brent Coffin and Richard Higgins

Kenneth R. Himes

Homicide in the Biblical World,

by Pamela Barmash

Beth Berkowitz

Roger Williams (Lives and Legacies),

by Edwin S. Gaustad

Timothy L. Hall

How Can a Christian be in Politics? A Guide Toward Faithful Politics, by Roy Herron

Robert F. Drinan

Gandhi's Way: A Handbook of Conflict Resolution, by Mark Juergensmeyer

Darrell Cole 
Sponsored by: Hamline University School of Law

Published by: $\quad$ Hamline University School of Law ISSN: 0748-0814 


\title{
THE JOURNAL OF LAW AND RELIGION
}

VOLUME XXI

2005-2006

NUMBER 1

\author{
EDITORIAL STAFF
}

Editor

MARIE A. FAILINGER, Hamline University School of Law

Associate Editors

PATRICK KEIFERT, Luther Theological Seminary

HOWARD J. VOGEL, Hamline University School of Law

Book Review Editor

LESLIE GRIFFIN, University of Houston Law Center

Technical Editors

MARY L. DUNNEWOLD, Hamline University School of Law

STEPHEN LIEBO, Hamline University School of Law

\section{Production/Subscription Manager}

LINDA BERGLIN, Hamline University School of Law

JENNIFER CHO

Editorial Assistants

CHRISTOPHER GANGL

TANEEZA ISLAM

Peter Navis

MARIT PETERSON

REBECCA PINERO

LINDSAY SHAW

KAREN WESTWOOD

\section{EDITORIAL BOARD}

JOSÉ ROBERTO JUAREZ, Saint Mary's University of San Antonio School of Law, Chair STEPHEN L. CARTER, Yale Law SChool

PAULA COOEY, Macalester College

ANTHONY E. COOK, Georgetown University Law Center

ANVER M. EMON, University of Toronto

MARIE FAILINGER, Hamline University School of Law Ex Officio

JON M. GARON, Hamline University School of Law

LESLIE C. GRIFFIN, University of Houston Law Center

Ex Officio

EMILY ALBRINK HARTIGAN, Saint Mary's University of San Antonio School of Law

AFRA JALABI, Islamic Scholar, Ile Perrot, Quebec

PATRICK R. KEIFERT, Luther Theological Seminary 
HOWARD LESNICK, University of Pennsylvania Law School RoBIN LOVIN, Perkins School of Theology, Southern Methodist University ELIZABETH MENSCH, State University of New York at Buffalo, School of Law NANCY MILLER-HERRON, Attorney at Law, Dresden, Tennessee, Secretary RUSSELL PEARCE, Fordham University School of Law MICHAEL PERRY, Emory University School of Law THOMAS PORTER, JUSTPEACE Center for Mediation \& Conflict Transformation RICHARD QUINNEY, Professor Emeritus, Northern Illinois University ASIFA QURAISHI, University of Wisconsin Law School EARL SCHWARTZ, Hamline University DARRYL TRIMIEW, Colgate Rochester Crozer Divinity School AMELIA UELMEN, Fordham University School of Law HOWARD J. VOGEL, Hamline University School of Law, Treasurer 
The Journal of Law and Religion is sponsored by the Hamline University School of Law and is a interdisciplinary, interfaith academic and professional publication devoted to investigating the interaction of religion and law.

Subscriptions to the Journal of Law and Religion, which is published twice annually, are $\$ 25$ per two-issue volume for individuals, $\$ 35$ for institutions, and $\$ 12$ for students. Add an additional $\$ 10$ for foreign postage. Subscription requests, manuscripts, and general correspondence should be addressed to:

\section{Journal of Law and Religion 1536 Hewitt Avenue \\ Saint Paul, Minnesota 55104 \\ lberglin@hamline.edu}

Book reviews and books to be reviewed should be addressed to: lgriffin@uh.edu

Citations generally conform to the Association of Legal Writing Directors' $A L W D$ Citation Manual. Citations to Jewish/Christian Biblical sources conform to the SBL Handbook of Style and the Jewish Law Annual. Unsolicited manuscripts will be returned only upon request.

Individual and back issues and complete sets of the Journal of Law and Religion may be ordered directly from William S. Hein \& Co., 1285 Main Street, Buffalo, New York 14209.

The views and opinions expressed in the Journal of Law and Religion are those of the authors and do not necessarily reflect the views of the editorial staff, the editorial board, the advisory board, or the sponsors of the Journal of Law and Religion.

Articles are indexed in the Index to Legal Periodicals published by the H.W. Wilson Co. (Bronx, New York), and in the Legal Resource Index available on-line on a variety of computer database services.

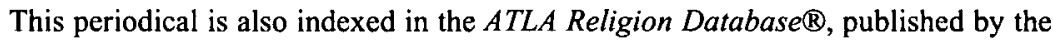
American Theological Library Association, 300 S. Wacker Dr., Suite 2100, Chicago, IL 60606,E-mail: atla@atla.com,WWW: http://www.atla.com/.

Internet access to information about the Journal of Law and Religion, including an index to past issues, is available at http://www.hamline.edu/law/jlr

All copyrights are reserved.

Cite as: 21 J. L. \& ReLIG. (2005-06) 


\section{ADVISORY COMMITTEE}

TAHA JABER AL-ALWANI, Graduate School of Social and Islamic Sciences AZIZAH AL-HIBRI, T.C. Williams School of Law, University of Richmond ABDULLAHI AN-NA'IM, Emory University School of Law

ZAFAR ISHAQ ANSARI, Islamic Research Institute, International Islamic University, Pakistan RICHARD BAEPLER, Professor Emeritus, Valparaiso University School of Law MILNER BALL, University of Georgia School of Law HAROLD BERMAN, Emory University School of Law GERARD BRADLEY, Notre Dame University Law School MICHAEL J. BROYDE, Emory University School of Law LYNN BUZZARD, Campbell University School of Law FRED CARNEY, Professor Emeritus, Perkins School of Theology, Southern Methodist University

ROBERT F. COCHRAN, JR., Pepperdine University School of Law MOHAMED S. EL-AWA, Islamic Scholar, Egypt

CARL ESBECK, University of Missouri-Columbia School of Law EDWARD MCGLYNN GAFFNEY, JR., Valparaiso University School of Law RICHARD HIERS, University of Florida CATHLEEN KAVENY, Notre Dame University Law School DAMIEN KEOWN, University of London, Goldsmiths SANFORD LEVINSON, University of Texas School of Law DAVID LITTLE, Harvard University Divinity School SEYYED HOSSEIN NASR, George Washington University LOUIS NEWMAN, Carleton College KAY PRANIS, Saint Paul, Minnesota

ELISABETH SCHÜSSLER FIORENZA, Harvard University Divinity School

THOMAS L. SHAFFER, Notre Dame University Law School STEVEN D. SMITH, University of San Diego School of Law DOUGLAS STURM, Professor Emeritus, Bucknell University PETER N. THOMPSON, Hamline University School of Law CHARLES VILLA-VICENCIO, Institute for Justice and Reconciliation, South Africa MICHAEL WELKER, University of Heidelberg, Germany JOHN WITTE, Jr., Emory University School of Law WILSON YATES, United Theological Seminary of the Twin Cities STEPHEN B. YOUNG, Attorney at Law, Saint Paul, Minnesota 


\title{
HAMLINE \\ UN IVERS I T Y \\ SCHOOL OF LAW
}

\section{A subscription to the \\ JOURNAL OF LAW AND \\ RELIGION}

\author{
Cost per volume (two issues): \\ $\$ 25.00$ individual (U.S.) \\ $\$ 35.00$ individual (foreign) \\ $\$ 35.00$ institution (U.S.) \\ $\$ 45.00$ institution (foreign) \\ $\$ 12.00$ student \\ Print and send to: \\ Circulation Manager \\ Journal of Law and Religion \\ Hamline University School of Law \\ 1536 Hewitt Avenue \\ St. Paul, MN 55104 \\ U.S.
}

Please Enclose Payment made out to:

Journal of Law and Religion

Name:

Address:

City:

State:

Zip:

Country:

Phone:

Fax:

E-Mail: 


\section{JOURNAL OF LAW AND RELIGION}

\section{STATEMENT OF PERSPECTIVE}

The Journal of Law and Religion was initiated in 1982 as a collaborative effort of the Council on Religion and Law and the Hamline University School of Law. It was born of a sense of historical malaise. The modern age with its strong propensity toward the secularization of all areas of life, while not without merit in its liberating effects, nonetheless has its dark side.

We live, some say, in a time of profound historical crisis. Domestically and globally, we confront massive issues which force us to reconsider, in fundamental ways, the shape and quality of our common life. Yet many of the disciplines of thought and practice that should be a rich resource in such a time are found wanting - among them, law and religion. Law, a discipline presumably devoted to the ways of justice, has all too often become a set of complex, technical tools without concern for higher purpose. Religion, presumably given to the all-embracing promises and prescriptions implied in the sense of the sacred, has all too often become privatized and neglectful of our public life.

The Journal of Law and Religion is dedicated to a fundamental reappraisal of the disciplines of law and religion as they impinge on each other, might instruct each other, and taken in their conjunction, might offer a constructive response to the major issues of our times. As such its concerns are sixfold.

Historical The Journal intends to encourage the examination of historical developments, movements, thinkers, and issues to enrich our understanding of how law and religion have, in various ways, been mutually influential.

Theoretical The Journal intends to promote constructive work in religious and legal thought about fundamental theological and jurisprudential questions pertaining to professional practice and the structures of our public life.

Ethical The Journal intends to support explorations into the foundations of ethical judgment and normative critiques of our social life, particularly as they draw upon resources from the life of law and religion.

Global The Journal intends to be encompassing in its reach, seeking out voices from all the religious and legal traditions throughout the world and bringing them into conversations with each other.

Professional The Journal intends to stimulate collaboration between jurists and religious leaders given their respective commitments, as professionals, to the common good of all peoples.

Spiritual The Journal recognizes that human existence is grounded in the spiritual, which is represented in many forms and expressions.

The Journal is thus a forum within which the disciplines of law and religion might together consider with utmost seriousness their joint responsibility for the creation of a civilization of genuine peace and justice. Within the compass of that purpose, the Journal intends to be open-minded and non-prejudicial; it is receptive to submissions from all persuasions and perspectives. 


\section{ANNOUNCEMENT}

We have acquired the entire back stock, reprint and microform rights to the

\section{JOURNAL OF LAW AND RELIGION}

Complete sets to date are now available. We can also furnish single volumes and issues.

\section{WILLIAM S. HEIN \& COMPANY, INC.}

\section{Main Street}

Buffalo, New York 14209-1987

Orders may also be placed by calling Hein at 800.828 .7571 ; via fax 716.883.8100; or found in electronic format for all your research needs on HeinOnline http://heinonline.org/ 


\begin{tabular}{|c|}
\hline Check out our website! \\
BOUThooks of Interest \\
Contemporary Conversations \\
Index of Issues \\
How to become a Subscriber \\
Lifetime Achievement Awards \\
Table of U.S. Supreme Court Decisions \\
Relating to Religious Liberty \\
Soon to be added: \\
Announcements of Coming Events
\end{tabular}




\section{THE JOURNAL OF LAW AND RELIGION}

\section{TABLE OF CONTENTS}

Editor's Preface xiii

\section{ARTICLES}

Patrick McKinley Brennan

Asking the Right Questions: Harnessing the Insights of Bernard Lonergan for the Rule of Law

Chaim Saiman

Legal Theology: The Turn to Conceptualism in Nineteenth-Century Jewish Law.

Gregory A. Kalscheur, S.J.

Christian Scripture and American Scripture:

An Instructive Analogy? 101

David VanDrunen The Use of Natural Law in Early Calvinist Resistance Theory.

\section{REVIEW ESSAYS}

Carolyn Evans

Religion in the World. 169

Marci A. Hamilton

Religion and Politics in the United States 173 


\section{BOOK REVIEWS}

Kenneth R. Himes

Taking Faith Seriously, edited by Mary Jo Bane, Brent Coffin and Richard Higgins.

Beth Berkowitz

Timothy L. Hall

Robert F. Drinan

Darrell Cole

Peter Clark

Stacey A. Tovino

Mark P. Strasser

David R. Dow

Stephen Parker
Homicide in the Biblical World, by Pamela Barmash

Roger Williams (Lives and Legacies), by Edwin S. Gaustad.

How Can a Christian be in Politics?

A Guide Toward Faithful Politics, by Roy Herron

Gandhi's Way: A Handbook of

Conflict Resolution,

by Mark Juergensmeyer.

Contemporary Catholic Health Care Ethics, by David F. Kelly.

Introduction to Jewish and Catholic Bioethics: A Comparative Analysis, by Aaron L. Mackler....

The Philosophy of Positive Law:

Foundations of Jurisprudence,

by James Bernard Murphy

Religion and the Death Penalty:

A Call for Reckoning, edited by Erik C. Owens, John D. Carlson and Eric P. Elshtain

In Good Faith: Schools, Religion and

Public Funding,

by Marie Parker-Jenkins, Dimitra Hartas

and Barrie A. Irving 
Betty Mensch

Jonathan Edwards, Gilead, and the Problem of "Tradition":

Gilead, by Marilynne Robinson;

Jonathan Edwards: A Life,

by George M. Marsden

James A.R. Nafziger Religion \& Security:

The New Nexus in International Relations, edited by Robert A. Seiple and

Dennis R. Hoover

Stacey A. Tovino

Jewish Biomedical Law:

Legal and Extra-legal Dimensions,

by Daniel B. Sinclair.

Dian Murray

Tibetan Buddhists in the Making of

Modern China,

by Gary Tuttle.

Stacey A. Tovino

The Birth of Surrogacy in Israel, by D. Kelly Weisberg

Anver M. Emon

Islamic Law and the Challenges of Modernity, edited by Yvonne Yazbeck Haddad and Barbara Freyer Stowasser. 